\title{
THE THOUGHT OF MUSLIM STUDENTS OF JAMBI UNIVERSITY IN RELATIONSHIP TO THE LIFE OF THE NATION AND THE STATE
}

\author{
Supian $^{1}$, K. A. Rahman ${ }^{2}$ \\ 1,2 Program Studi Ilmu Sejarah, Universitas Jambi \\ Email: ${ }^{1}$ supian.ramli@unja.ac.id, ${ }^{2} \mathrm{Ka} \_$rahman@unja.ac.id \\ DOI: https://doi.org/10.29313/tjpi.v9i1.5998 \\ Submitted: May 03th, 2020. Approved: June 20th, 2020. Published: June 20th, 2020
}

\begin{abstract}
This study aims to determine the style of thinking of active students at the University of Jambi by asking 16 questions or statements related to Islamic understanding and its relationship with national and state life. The number of samples or respondents in 2012, which means almost 10\% of about 24.100 active Muslim students in the University of Jambi were contributed to this study. This research conducted through the online academic information system at the University of Jambi. Based on gender, there are 970 male respondents (48.21\%) and 1,043 female respondents (51.84\%). The respondents represent each study program and faculty at the University of Jambi who have taken the time to fill out the questionnaire. This is a simple random sampling, the sampling technique of population members is selected randomly without regard to strata in the population. In general, from these 16 questions, it is illustrated that the majority of students are still in the corridor that is in line with the Indonesian Islamic community. Based on the result of the study, it is found that the students who have the moderate line are in the range of 75-85\%, while those who are still in the gray line or are in doubt answers range between 7 $12 \%$, and the students who have the consistent answers on the radical line range from $0-3 \%$. This finding occurs in 15 questions, however on one question or statement relating to the probibition of HTI (Hizbut Tabrir Indonesia) there is an increase in the percentage of understanding in which contrary to moderate understanding. This shows the intensity, understanding and propaganda that are developed and understood by students, resulting in a greater tendency to disagree with the prohibition of $\operatorname{HTI}(10.19 \%)$.
\end{abstract}

Keywrods: Style of Thinking; Muslim Students; Moderat; Radical.

\begin{abstract}
Abstrak
Penelitian ini bertujuan untuk mengetahui corak pemikiran mahasiswa aktif Universitas Jambi dengan mengajukan 16 pertanyaan atau pernyataan yang berbubungan dengan pemahaman keislaman dan bubungannya dengan kehidupan berbangsa dan bernegara. Jumlah sampel atau responden 2012 orang, yang berarti hampir $10 \%$ dari sekitar 24.100 mahasiswa Muslim aktif yang ada di Universitas Jambi, melalui siakad Universitas Jambi (online). Berdasarkan jenis kelamin terdiri dari 970 orang responden laki-laki (48,21\%) dan 1.043 orang responden perempuan (51,84 \%). Responden mewakili setiap prodi dan Fakultas yang ada di Universitas Jambi yang telah menyempatkan diri untuk mengisi kuesioner tersebut, ini merupakan bentuk simple random sampling, yakni teknik pengambilan sampel dari anggota populasi dilakukan secara acak tanpa memperhatikan strata yang ada dalam populasi itu. Secara umum dari 16 pertanyaan tersebut tergambar bahwa mayoritas mahasiswa masib berada pada koridor yang sesuai dengan masyarakat Islam Indonesia pada umumnya, mahasiswa yang berpikir moderat berkisar antara 75-85\%, sedangkan yang masib berada di garis abu-abu atau berada pada jawaban keraguan berkisar antara 7-12\%, dan yang konsisten jawabannya pada garis yang radikal berkisar antara 0-3\%. Temuan ini terjadi pada 15 pertanyaan. Tetapi pada satu pertanyaan atau pernyataan yang berbubungan dengan pelarangan HTI ada peningkatan prosentase dari pemahaman yang berlawanan dengan pemahaman yang moderat. Hal ini menunjukkan adanya intensitas, pemahaman dan propaganda yang banyak berkembang dan difahami oleh mahasiswa sehingga pemahamannya cenderung lebih besar kepada tidak setuju terhadap pelarangan HTI (10,19\%).
\end{abstract}

Kata Kunci: Corak Pemikiran; Mahasiswa Muslim; Moderat; Radikal. 


\section{PENDAHULUAN}

Dalam studi keagamaan, ada empat definisi mengenai agama, yaitu: creed, code, cult, and community. Creed adalah kepercayaan tentang sesuatu yang secara mutlak dianggap benar bagi kehidupan manusia. Code; pedoman tata tindak (perilaku) yang timbul akibat adanya kepercayaan di atas. Cult, upaya manusia untuk menyelaraskan dirinya dengan yang dipercayai tadi, baik sebagai cara untuk memahami kehendaknya atau memperbaiki kembali kesalahan manusia yang tidak sesuai dengan kehendak kepercayaan tadi. Serta community; adanya kenyataan suatu umat yang terikat dalam kepercayaan, tindakan etik dan kultus tadi (Shofiyullah dalam (Usman, 2006, hal. 155156)). Sehingga ketika keempat syarat tadi mampu dipenuhi oleh sebuah lembaga atau institusi maka hal itu bisa disebut dengan istilah agama.

Diakui bahwa Indonesia bukan negara agama, meskipun demikian nilai-nilai agama sangat dominan menjiwai rakyatnya dalam kehidupan pribadi, berkeluarga, bermasyarakat, berbangsa dan bernegara. Lebih-lebih dalam konteks Indonesia, negara yang mayoritas penduduknya beragama Islam dan menjadi tumpuan kemajuan dunia Islam di masa yang akan datang, maka ruh agama tidak dapat dipisahkan dari masyarakatnya. Maka tidaklah mengherankan apabila agama dalam berbagai aspek dan manifestasinya mendapatkan perhatian besar di negeri ini.

Sebagai agama mayoritas, tentunya Islam tidak hanya menjadi pengikat keyakinan masyarakat dalam beragama dan beramal ibadah, tetapi juga menjadi bagian dan denyut nadi dalam kehidupan masyarakat, yang mewarnai semua aspek kehidupan, sosial budaya, ekonomi dan pendidikan. Dan secara sosio-kultural, Islam di Indonesia merupakan gambaran Islam yang moderat, tradisionalis dan menghargai nilai-nilai perbedaan di tengah-tengah umatnya, demikian pula harusnya yang terjadi di sebuah Universitas atau PTU sebagai sebuah miniatur dari Indonesia. Artinya keragaman dan kebersamaan dalam bentuk nasionalisme bangsa, harusnya juga tercermin dalam kalangan akademik dan dunia intelektual di sebuah perguruan tinggi.

Maka menjadi menarik untuk dikaji, ketika di Perguruan Tinggi seperti Universitas Jambi, bagaimana corak pemikiran keagamaan mahasiswa dengan berbagai latar belakangnya hingga kemudian bagaimana sikap dan eksistensi mereka terhadap kehidupan berbangsa dan bernegara, khususnya dalam pemahaman mereka terhadap empat pilar bernegara, yakni Pancasila, Undang-Undang Dasar 1945, NKRI dan Bhinneka Tunggal Ika.

Mahasiswa yang merupakan insan intelektual dan harapan masa depan bangsa, seharusnya memiliki nilai-nilai penghargaan, kebersamaan dan inklusifisme dalam keragaman bangsa dan keragaman pemahaman, gerakan, aliran dan organisasi Islam di Indonesia, tetapi secara bersamasama dapat menopang kehidupan berbangsa dan bernegara. Lebih jauh keadaan yang berada pada posisi sebaliknya dapat menumbuh kembangkan doktrin-doktrin yang boleh jadi membahayakan potensi keragaman dalam kehidupan bernegara seperti yang banyak disinyalir munculnya radikalisme (Turmudi \& Sihbudi, 2005) dan Gerakan mahasiswa di PTU yang mengkhawatirkan, di antara dampak atau ciriciri yang bisa dirasakan adalah adanya kelompok-kelompok pengajian yang eksklusif, menyendiri, kalau bergaul tidak begitu kelihatan, bahkan mereka tidak mau bersalaman dengan orang tua, berani melawan orang tua, menganggap orang tua, tidak mau hormat bendera serta pegawai negeri dan NKRI sebagai kafir (Mubarok, 2011), sehingga ada ketakutan di beberapa elemen masyarakat untuk mempercayakan pendidikan anaknya di PTU seperti di Universitas Jambi.

Dalam beberapa studi literatur, hubungan antara agama dan negara di Indonesia sudah mengkristal dan dianggap final. Mengutip pernyataan Prof. Nasaruddin Umar, Imam Besar Masjid Istiqlal Jakarta, bahwa Islam di Indonesia memiliki perannya sendiri, mulai dari gerakan yang berhasil mendorong pemeluknya berdiri menegakkan keadilan dan mengusir penjajah. Islam beserta 
pranatanya menjadi barisan yang begitu kuat memberikan perlawanan, hingga akhirnya Indonesia merdeka. Peran Islam tetap nyata dan tak terbantahkan. Kontribusi Islam terhadap bangsa ini tidak hanya bersifat fisik. Tegaknya NKRI banyak dipengaruhi berbagai faktor, baik politik, ekonomi, keamanan dan agama. Islam sebagai agama yang men-drive pemeluknya menjadi shaleh secara individual dan sosil, menempati perannya yang amat sentral dalam menjaga keutuhan NKRI (Umar, 2019).

Umat Islam Indonesia hadir sebagai teladan dalam menjaga kerukunan bangsa dan negara. Islam hadir di gugusan nusantara membawa seluruh energi positifnya, memberi warna yang terbaik bagi bangsa Indonesia yang plural ini. Islam hadir sebagai agama rahmat, agama yang tidak hanya mengajarkan kesalehan individual, namun juga mendorong pemeluknya memiliki kesadaran dan kepedulian sosial.

Namun di beberapa dekade terakhir, muncul fenomena radikalisme di Indonesia, termasuk radikalisme dalam bernegara. Suarasuara yang menginginkan perubahan radikal seperti NKRI Bersyari'ah, mengganti Pancasila, mendirikan negara Islam atau sistem Khilafah, menolak sistem demokrasi dan beberapa persoalan yang menggugat hubungan antara agama dan negara yang sudah mapan dilaksanakan di Indonesia. Fenomena dan keadaan ini kelihatan semakin menguat di tengah-tengah masyarakat seiring dengan kemajuan sistem informasi dan canggihnya media sosial. Propaganda yang demikian massif secara tersembunyi atau melalui media sosial membuat banyak umat Islam dan anak bangsa yang turut simpati dan bahkan mendukung, termasuk di kalangan mahasiswa.

Dahsyatnya kemajuan teknologi saat ini, diibaratkan laksana pedang bermata dua, karena selain memberikan kontribusi positif bagi peningkatan kesejahteraan, kemajuan dan peradaban manusia, juga sekaligus membawa virus negatif dan menjadi sarana efektif untuk melakukan kejahatan dan perbuatan yang melanggar hukum lainnya yang menyerang berbagai kepentingan orang, masyarakat hingga Negara (Ramli, 2004, hal.
1). Di era teknologi informasi saat ini, media elektronik maupun media sosial memainkan peran yang sangat penting dalam menciptakan kesan (image) di tengah-tengah masyarakat. Apa yang nampak dimedia tersebut seringkali diterima masyarakat luas sebagai suatu kebenaran (Engineer, 2004, hal. 146). Kenyataan ini tentu menjadi kesempatan besar bagi oknum-oknum yang tidak bertanggungjawab untuk membuat, memposting dan menyebarluaskan kontenkonten negatif yang berisi informasi hoaks, fitnah dan ujaran kebencian kepada khalayak umum melalui media elektronik maupun media sosial, sehingga menimbulkan kontroversi dimasyarakat yang berpeluang mengancam retaknya semangat persatuan dan kesatuan bangsa.

Gerakan radikalisme agama ini merambah kepada masyarakat begitu cepat. Fenomena ini juga banyak dipengaruhi oleh media-media kanan yang banyak bermunculan di tengah-tengah masyarakat. Media seperti itu seringkali menghembuskan ajaran-ajaran atau berita-berita yang sinis terhadap ajaran di luar kelompoknya. Muncul pula ustaz atau pengkhutbah yang seringkali menggambarkan Islam bukan dengan wajah kedamaian, kesejukan dan rahmat, tetapi sering dengat kutukan, penyesatan, dan penghinaan dan laknat kepada kelompokkelompok lainnya sehingga umat Islam menjadi terpengaruh dan terprovokasi (Rahmat, 2012, hal. 20).

Gejala radikalisme tersebut sudah mulai dirasa, dan yang berkembang di masyarakat di antaranya ditandai dengan beberapa hal: Pertama, kecenderungan untuk menafsirkan teks secara leterlek dengan mengabaikan konteks, kedua, adanya orientasi terhadap penegakan syari'ah (atau syari'ab minded) bahkan khilafah, dan ketiga, adanya kecenderungan bersifat eksklusif, anti toleran dan anti pluralisme (Rahmat, 2012, hal. 21). Lebih jauh keadaan ini berinbas juga kepada mahasiswa dan generasi muda, sehingga memunculkan kegalauan di kalangan generasi muda (Syafruddin \& Ismatu, 2018).

Merujuk kepada tulisan dan temuan survey Denny JA (Arismunandar, 2019) yang meneliti tentang masalah-masalah 
krusial yang terkait dengan demokrasi dan masa depan Indonesia. Tulisan Denny JA ini tidak hadir begitu saja. Tulisan Denny sebenarnya berangkat dari keprihatinan, menyusul hasil survei Lingkaran Survei Indonesia (LSI) Denny JA, yang melakukan survei analisis pro-Pancasila. Ternyata menurut survei, dalam 13 tahun terakhir, persentase publik pro-Pancasila terus menurun sebanyak 10 persen.

Menurut Azra dalam (Fuaduddin \& Basri, 2002, hal. 224), ketika ingin melihat corak berpikir mahasiswa muslim, maka ada tiga kelompok mahasiswa; (1) Kelompok mayoritas, adalah kelompok "common" Muslim, yakni para mahasiswa Muslim yang mengamalkan agama Islam mengikuti umumnya Muslim di Indonesia, dan cenderung bersifat tradisional dan konvensional. (2) Kelompok para mahasiswa yang sangat kuat latar belakang keagamaannya dan mereka yang merasa perlu mengembangkan dirinya, meningkatkan pemahaman mereka tentang Islam, dan dalam konteks akademis mereka berusaha untuk meningkatkan kemampuan berorganisasi dan keterampilan ilmiah dan biasanya memilih dan bergabung dengan kemahasiswaan Islam, (3) Kelompok yang muncul belakangan, yakni kelompok yang lebih berorientasi kepada pengamalan Islam secara menyeluruh, Kaffah, membentuk kajian-kajian yang intensif melalui Usroh-usroh, Liqo'-Liqo', dan merupakan pengaruh gerakan organisasi internasional Islam seperti Ikbwanul Muslimin (Mesir), Jema'at Islami (Pakistan) atau juga merupakan kreasi lokal mahasiswa Islam Indonesia sendiri.

Sementara (Rahmat, 2012, hal. 13) mengelompokkan corak pemikiran mahasiswa Muslim kepada tiga kelompok mahasiswa; Pertama, Eksklusif, yaitu kelompok yang tertutup, cenderung keras dan radikal. Dalam tataran politis mereka menganggap bahwa pemerintahan yang bukan berdasarkan Islam, sebagai pemerintahan thoghut yang harus dilawan. (Azra, Ali dan Mukawi dalam (Fuaduddin \& Basri, 2002)). Kedua, Inklusif, adalah corak berpikir yang terbuka, moderat dan corak berpikir keagamaan yang sesuai dengan citacita pendidikan nasional Indonesia, yang juga sesuai dengan nilai-nilai Islam yang rahmatan li al-'alamin. (Rahmat, 2012, hal. 23). Ketiga, Liberal, yang secara harfiah berarti bebas dan menganggap semua agama sama. Menurut (Rahmat, 2012, hal. 21-23), adalah suatu bentuk penafsiran "baru" terhadap agama Islam. Pemikiran kelompok liberal yang disosialisasikan di Indonesia, antara lain menolak dikotomi Muslim Versus nonMuslim, Pernikahan antar agama yang tidak perlu dipersoalkan lagi, dan beberapa pemahaman sekuler lainnya.

Gerakan radikalisme dalam beragama, akhir-akhir ini semakin menggema, terbuka dan merambah kepada masyarakat dengan begitu cepat. Mereka seolah-olah mendapatkan momentum melalui media-media online dan media sosial, terutama media-media kanan yang banyak bermunculan di tengah-tengah masyarakat. Media seperti itu sering kali menghembuskan berita-berita dan pernyataan-pernyataan sinis terhadap ajaran dan pendapat kelompok lain di luar kelompoknya. Bahkan sering kali pernyataan-pernyataan tersebut tidak disampaikan dengan kelembutan, kedamaian dan kesejukan, tapi justru disampaikan dengan kutukan, penyesatan, pengkafiran dan penghinaan terhadap kelompok-kelompok selain mereka. Akibatnya tidak sedikit umat yang terpengaruh dan terprovokasi.

Dalam konteks hubungan antara agama dan negara, maka radikalisme berarti ingin menggantikan sistem demokrasi yang sudah dijalankan di Indonesia dengan sistem khilafah, ingin menggantikan Negara Kesatuan Republik Indonesia (NKRI) dengan negara Islam dan mengganti Pancasila dengan Hukum Islam. Meskipun secara resmi Hizbut Tahrir Indonesia (HTI) yang mengusung tema khilafah sudah dibubarkan, tetapi pengaruh dan sebaran pemikirannya sudah merambah sampai kepada mahasiswa, tidak terkecuali mahasiswa Universitas Jambi.

Salah seorang mahasiswi yang sudah peneliti anggap terpapar faham radikal tersebut ditanya melalui media Whatshapp, menggambarkan keadaan tersebut. Terkait ideologi khilafah ia mengatakan bahwa 
khilafah itu berjuang menerapkan Islam secara kaffah, dan menganggap orang yang menolak khilafah adalah orang-orang yang tidak suka dengan dakwah Islam, dan pembubaran HTI adalah cara pemerintah untuk membungkam dakwah Islam. (Lusiyana, 2019). Seorang mahasiswi lain menganggap penolakan ideologi khilafah merupakan Islamophobia, demikian pula penolakan pemakaian cadar dan menganggap itu propaganda Barat untuk menghalangi tegaknya Islam". (Aryani, 2019). Kedua mahasiswi tersebut baru terpengaruh atau terpapar faham tersebut, karena sebelumnya keduanya masih seperti mahasiswa pada umumnya. Keduanya diketahui sering mengikuti kajian dan pengajian yang bersifat eksklusif, terselubung dan ekstra universitas. Tetapi pengaruh bagi keduanya sudah cukup kuat sehingga sulit untuk diberikan pemahaman yang moderat. Bagi keduanya sudah berpantang surut dari pendapatnya tersebut, karena menganggap Indonesia belum menerapkan aturan Islam sehingga tergolong negara kafir. (Lusiyana, 2019).

Menurut Muhibbuddin, para aktifis Islam kampus yang "baru" mengenal Islam tersebut, kemudian seolah-olah sudah menjadi orang yang paling Islam, sudah merasa menjadi orang yang paling paham tentang Islam, sehingga mudah mengkafirkafirkan dan membid'ah-bid'ahkan para ulama dan cendekiawan yang sudah menekuni keislaman selama berpuluh-puluh tahun. Sesungguhnya pengetahuan dan keilmuan mereka masih keropos, dengan berbekal pengetahuan yang cenderung literal dan tekstual, kemudian mulai memakai jubah, cadar, berjenggot dan pola komunikasi yang kearab-araban, Ya Akbi, Ya Ukbti, bagaimana kabar Antum? Ana di sini, Ilalliqo' dan lainlain, kemudian merasa sebagai satu-satunya representasi Islam dan yang paling tinggi Islamnya (Muhibbuddin, 2012, hal. 61-62).

Dan sebagaimana hasil penelitian yang dilakukan oleh (Rahmat, 2012, hal. 27), bahwa responden yang aktif di organisasi ekstra KAMMI dan HTI lebih dominan pada corak berpikir eksklusif. Fenomena eksklusivisme keagamaan di kampus PTU memang merupakan fenomena umum dewasa ini. Dalam beberapa kali pertemuan Nasional Dosen PAI di PTU, sinyalemen tersebut semakin kuat dan diakui oleh utusanutusan PTU dari seluruh Indonesia. Tetapi semua mereka hampir masih memiliki pemikiran yang sama, menghentikan aktivitas mereka sama saja dengan mematikan kegiatan atau aktivitas agama. Selain itu kegiatan mereka juga sangat membantu dalam suasana kehidupan keagamaan di kampus. Sedangkan membiarkan mereka sama saja dengan membiarkan menguatnya corak pemikiran keagamaan yang eksklusif. Sehingga seperti buah "simalakama", dimakan ibu mati, tidak dimakan bapak mati.

Keberadaan beberapa organisasi yang disinyalir sebagai cikal bakal terjadinya eksklusivisme dan radikalisme tersebut juga didukung oleh beberapa temuan, bahkan Peneliti Lembaga Ilmu Pengetahuan Indonesia (LIPI) Anas Saidi ("Peneliti LIPI sebut Organisasi Kemahasiswaan Kammi Ajarkan Ideologi Radikalisme," 2016) mengatakan radikalisme ideologi telah merambah dunia mahasiswa melalui proses Islamisasi. Proses itu dilakukan secara tertutup dan menurutnya, berpotensi memecah belah bangsa. "Radikalisme ideologi jikea tidak dicegah dari sekarang bukan mustabil Indonesia menjadi negara yang porak poranda dan dipecah karena perbedaan ideologis," kata Anas saat diskusi Membedah Pola Gerakan Radikal, di Gedung LIPI, Jakarta, Kamis (18/2/2016).

Pasca reformasi, peta gerakan mahasiswa telah mengalami banyak perubahan. Kelompok Cipayung yang sebelumnya dianggap mendominasi gerakan Islam di kampus, kini digeser oleh kelompok lain yang turut menyebarkan radikalisasi ideologi. Yang terkadang seolah-olah mendapat dukungan dan simpati di kalangan mahasiswa. Anas menyebut beberapa organisasi kemahasiswaan itu, salah satunya adalah Kesatuan Aksi Mahasiswa Muslim Indonesia (KAMMI). Kelompok ini dinilai memiliki hubungan ideologis dengan kelompok radikal internasional Ikhwanul Muslimin, "Hampir tidak ada dunia mahasiswa yang tidak dikuasai oleh kelompok Ikhwanul Muslimin, Salafi dan Hizbut Tahrir 
Indonesia. KAMMI adalah kepanjangan dari Ikhwanul Muslimin”, kata Anas. Di kampus, lanjut Anas, kelompok ini lebih banyak melakukan radikalisasi ideologi dengan citacita mendirikan negara Islam versi mereka sendiri. Jika hal ini tidak dicegah secepatnya, menurut Anas, kemungkinan besar Indonesia akan terjadi perang saudara di masa yang akan datang. ("Peneliti LIPI sebut Organisasi Kemahasiswaan Kammi Ajarkan Ideologi Radikalisme," 2016)

Menurut peneliti LIPI lainnya, Endang Turmudi, kelompok seperti Ikhwanul Muslimin memiliki pandangan keyakinan dan sikap fundamentalisme puritan kaku. Mereka selalu merasa paling benar dan menganggap kelompok lain salah. Tujuan mereka membangun negara Islam, bahkan untuk mewujudkannya dibolehkan menggunakan cara-cara kekerasan. "Mereka yang tidak mendirikan negara Islam dianggap kafir, halal untuk diperangi karena Thoghut," kata Endang. ("Peneliti LIPI sebut Organisasi Kemahasiswaan Kammi Ajarkan Ideologi Radikalisme," 2016)

Radikalisasi ideologi yang dilakukan di kampus juga mengancam ideologi Pancasila. Berdasarkan hasil riset Anas, mahasiswa yang belajar ilmu eksak lebih mudah direkrut oleh kelompok radikal dibandingkan mahasiswa di bidang ilmu sosial. Proses perekrutan, jaringan, hingga pemeliharaan jaringan mereka lakukan secara terorganisir.

Anas menunjukkan hasil survey, bahwa 25 persen siswa dan 21 persen guru menyatakan Pancasila tidak relevan lagi, sementara 84,8 persen siswa dan 76,2 persen guru menyatakan setuju dengan penerapan syari'at Islam. Sementara pada survey tahun lalu, 4 persen orang Indonesia menyetujui kelompok militan ISIS, mereka berumur 1925 tahun, sedangkan 5 persen di antaranya adalah mahasiswa. "Kalau data ini dapat dipercayai, maka 10 juta umat Islam Indonesia simpatik kepada ISIS, itu sungguh angka yang mengejutkan" ujar Anas. ("Peneliti LIPI sebut Organisasi Kemahasiswaan Kammi Ajarkan Ideologi Radikalisme," 2016)
Berkaca dengan latar belakang seperti itulah penelitian ini dimaksudkan untuk melihat corak pemikiran keagamaan mahasiswa Muslim Universitas Jambi dan hubungannya dengan kehidupan berbangsa dan bernegara. Mengutip kembali (Umar, 2019, hal. 420), seberapa kuat daya tahan Islam di Indonesia di tengah serbuan ismeisme, baik isme yang mengambil tema luar seperti liberalisme, sekulerisme, materialisme, pragmatisme dan semacamnya, maupun isme dari dalam (from within) seperti paham NII, ISIS, HTI, AlQaida, Salafi-Jihadi, Ahmadiyah, Wahabi, Syi'ah dan semacamnya.

\section{METODE PENELITIAN}

Penelitian ini merupakan penelitian lapangan (Field Research) (Muhajir, 1992). Objek penelitian ini adalah Corak Pemikiran Kegamaan dan Sikap terhadap kehidupan berbangsa dan bernegara, objek utama adalah mahasiswa Universitas Jambi. Penelitian dilaksanakan dengan random sample melalui siakad Universitas Jambi. Target penelitian ini ialah mendeskripsikan dan menganalisa Corak Pemikiran Keagamaan mahasiswa Universitas Jambi dalam hubungannya dengan kehidupan berbangsa dan bernegara.

Data-data yang sudah di dapat, kemudian diuji validitasnya, di analisa dan disimpulkan menjadi sebuah bagan yang menunjukkan corak pemikiran keagamaan mahasiswa dan sikap mereka terhadap persoalan-persoalan kehidupan berbangsa dan bernegara. Dalam penelitian ini validitas data diuji dengan menggunakan trianggulasi data, yakni peneliti menggunakan beberapa sumber data untuk mendapatkan data yang sejenis, sehingga didapat pemahaman lintas data yang menyeluruh. Model yang digunakan dalam analisis data ini mengambil model analisis interaktif komparatif, yakni ketiga komponen analisis data saling berinteraksi selama proses penelitian (Krippendorff, 1993). Analisis ini dengan demikian dilakukan di lapangan dan dicatat dalam fieldnotefieldnote untuk selanjutnya hasilnya 
digunakan dalam penyusunan laporan penelitian final.

Latar belakang responden yang sudah dianalisa, dapat dilaporkan sebagai berikut: Responden yang valid dalam penelitian ini berjumlah 2012 orang, yang berarti hampir $10 \%$ dari sekitar 24.100 mahasiswa Muslim aktif yang ada di Universitas Jambi. Berdasarkan jenis kelamin terdiri dari 970 orang responden laki-laki (48,21\%) dan 1.043 orang responden perempuan (51,84\%). Responden mewakili setiap prodi dan Fakultas yang ada di Universitas Jambi yang telah menyempatkan diri untuk mengisi kuesioner tersebut, ini merupakan bentuk simple random sampling, yakni teknik pengambilan sampel dari anggota populasi dilakukan secara acak tanpa memperhatikan strata yang ada dalam populasi itu (Sugiyono, 2001, hal. 57), suatu teknik pengambilan sampel atau elemen secara acak, dimana setiap elemen atau anggota populasi memiliki kesempatan yang sama untuk terpilih menjadi sampel.

\section{PEMBAHASAN}

Untuk menemukan corak pemikiran mahasiswa Muslim di Universitas Jambi dan hubungannya dengan Kehidupan berbangsa dan bernegara, maka diajukan sebanyak 16 pertanyaan penelitian yang berhubungan dengan pemahaman, sikap, pengetahuan dan keyakinan terhadap hubungan bangsa dan negara, dan berdasarkan hasil yang didapat paparan sebagai berikut :

\begin{tabular}{|c|c|c|c|c|}
\hline No. & Pertanyaan (Jenis Pertanyaan) & Criteria & Frequency & Prosentase \\
\hline \multirow{5}{*}{1.} & \multirow{5}{*}{$\begin{array}{l}\text { Islam adalah agama yang rabmatan lil 'alamin } \\
\text { Dan Islam di Indonesia memiliki nilai dan } \\
\text { pemahaman yang moderat }\end{array}$} & SS & 1079 & $53,63 \%$ \\
\hline & & $\mathrm{S}$ & 842 & $41,85 \%$ \\
\hline & & $\mathrm{R}$ & 73 & $3,63 \%$ \\
\hline & & TS & 11 & $0,55 \%$ \\
\hline & & STS & 8 & $0,40 \%$ \\
\hline \multirow{5}{*}{2.} & \multirow{5}{*}{$\begin{array}{l}\text { Perbedaan-perbedaan yang ada seperti } \\
\text { perbedaan mazhab, pemikiran, pandangan } \\
\text { dan pilihan politik adalah sebuah sunnatullah } \\
\text { yang harus dijaga dan saling menghormati }\end{array}$} & SS & 1020 & $50,70 \%$ \\
\hline & & $\mathrm{S}$ & 920 & $45,73 \%$ \\
\hline & & $\mathrm{R}$ & 61 & $3,03 \%$ \\
\hline & & TS & 8 & $0,40 \%$ \\
\hline & & STS & 4 & $0,20 \%$ \\
\hline \multirow{5}{*}{3.} & \multirow{5}{*}{$\begin{array}{l}\text { Jihad adalah kesungguhan hati dan jiwa dalam } \\
\text { beramal ibadah menuju kesalehan spiritual } \\
\text { dan kesalehan sosial }\end{array}$} & SS & 743 & $36,93 \%$ \\
\hline & & $\mathrm{S}$ & 1058 & $52,58 \%$ \\
\hline & & $\overline{\mathrm{R}}$ & 180 & $8,95 \%$ \\
\hline & & TS & 27 & $1,34 \%$ \\
\hline & & STS & 5 & $0,25 \%$ \\
\hline \multirow{5}{*}{4.} & \multirow{5}{*}{$\begin{array}{l}\text { Di dalam Islam, Bid'ah dapat dibagi dua, } \\
\text { yakni Bid'ah Hasanah, yakni Bid'ah yang baik } \\
\text { dan Bid'ah Sayyi'ah, Bid'ah yang tidak baik atau } \\
\text { sesat }\end{array}$} & SS & 738 & $36,68 \%$ \\
\hline & & $\mathrm{S}$ & 1041 & $51,74 \%$ \\
\hline & & $\mathrm{R}$ & 182 & $9,05 \%$ \\
\hline & & TS & 46 & $2,29 \%$ \\
\hline & & STS & 6 & 0,30 \\
\hline \multirow{5}{*}{5.} & \multirow{5}{*}{$\begin{array}{l}\text { Antara Islam (agama) dan Indonesia (negara) } \\
\text { tidak boleh dipertentangkan, karena Islam } \\
\text { di Indonesia sudah mendapatkan tempat yang } \\
\text { terbaik }\end{array}$} & SS & 738 & $36,68 \%$ \\
\hline & & $\mathrm{S}$ & 1041 & $51,74 \%$ \\
\hline & & $\mathrm{R}$ & 182 & $9,05 \%$ \\
\hline & & TS & 46 & $2,29 \%$ \\
\hline & & STS & 6 & $0,30 \%$ \\
\hline \multirow{5}{*}{6.} & \multirow{5}{*}{$\begin{array}{l}\text { Pancasila adalah alat perekat dan pemersatu } \\
\text { bangsa yang berbeda, beragam dan majemuk }\end{array}$} & SS & 1142 & $56,76 \%$ \\
\hline & & $\mathrm{S}$ & 818 & 40,66 \\
\hline & & $\mathrm{R}$ & 46 & $2,29 \%$ \\
\hline & & TS & 6 & $0,30 \%$ \\
\hline & & STS & 1 & $0,05 \%$ \\
\hline
\end{tabular}




\begin{tabular}{|c|c|c|c|c|}
\hline \multirow{5}{*}{7.} & \multirow{5}{*}{$\begin{array}{l}\text { Pancasila adalah satu-satunya ideologi negara } \\
\text { dan bersifat final }\end{array}$} & SS & 919 & $45,68 \%$ \\
\hline & & $\mathrm{S}$ & 943 & $46,87 \%$ \\
\hline & & $\mathrm{R}$ & 124 & $6,16 \%$ \\
\hline & & TS & 22 & $1,09 \%$ \\
\hline & & STS & 5 & $0,25 \%$ \\
\hline \multirow{5}{*}{8.} & \multirow{5}{*}{$\begin{array}{l}\text { HTI adalah organisasi yang dilarang di } \\
\text { Indonesia, karena ingin mendirikan sistem } \\
\text { khilafah }\end{array}$} & SS & 346 & $17,20 \%$ \\
\hline & & $\mathrm{S}$ & 738 & $36,68 \%$ \\
\hline & & $\mathrm{R}$ & 724 & $35,98 \%$ \\
\hline & & TS & 159 & $7,90 \%$ \\
\hline & & STS & 46 & $2,29 \%$ \\
\hline \multirow{5}{*}{9.} & \multirow{5}{*}{$\begin{array}{l}\text { Republik Indonesia yang beragam suku, agama, } \\
\text { bahasa dan adat istiadat harus dijaga dengan } \\
\text { kebersamaan dan toleransi }\end{array}$} & SS & 1206 & $59,94 \%$ \\
\hline & & $\mathrm{S}$ & 763 & $37,92 \%$ \\
\hline & & $\mathrm{R}$ & 34 & $1,69 \%$ \\
\hline & & TS & 7 & $0,35 \%$ \\
\hline & & STS & 3 & $0,15 \%$ \\
\hline \multirow{5}{*}{10.} & \multirow{5}{*}{$\begin{array}{l}\text { Di Indonesia, antara Muslim dan non-Muslim } \\
\text { harus saling menghormati, karena merupakan } \\
\text { sesama saudara sebangsa }\end{array}$} & SS & 1383 & $68,74 \%$ \\
\hline & & $\mathrm{S}$ & 601 & $29,87 \%$ \\
\hline & & $\mathrm{R}$ & 23 & $1,14 \%$ \\
\hline & & TS & 4 & $0,20 \%$ \\
\hline & & STS & 2 & $0,10 \%$ \\
\hline \multirow{5}{*}{11.} & \multirow{5}{*}{$\begin{array}{l}\text { Radikalisme termasuk hal yang berbahaya bagi } \\
\text { bangsa Indonesia, karena dapat merusak tatanan } \\
\text { dan nilai adat dan budaya bangsa, serta } \\
\text { kehancuran bangsa }\end{array}$} & SS & 899 & $44,68 \%$ \\
\hline & & $\mathrm{S}$ & 943 & $46,87 \%$ \\
\hline & & $\mathrm{R}$ & 130 & $6,46 \%$ \\
\hline & & TS & 24 & $1,19 \%$ \\
\hline & & STS & 17 & $0,84 \%$ \\
\hline \multirow{5}{*}{12.} & \multirow{5}{*}{$\begin{array}{l}\text { Indonesia harus belajar dengan beberapa negara } \\
\text { yang senantiasa berada dalam konflik dan } \\
\text { peperangan karena tidak memiliki persatuan } \\
\text { dan ukhuwah wathoniyah. }\end{array}$} & SS & 380 & $18,89 \%$ \\
\hline & & $\mathrm{S}$ & 795 & $39,51 \%$ \\
\hline & & $\mathrm{R}$ & 525 & $26,09 \%$ \\
\hline & & TS & 243 & $12,08 \%$ \\
\hline & & STS & 70 & $3,48 \%$ \\
\hline \multirow{5}{*}{13.} & \multirow{5}{*}{$\begin{array}{l}\text { Nabi Muhammad SAW sangat mencintai bang- } \\
\text { sa Arab karena Nabi Muhammad SAW adalah } \\
\text { keturunan Arab, sedangkan kita harus mencin- } \\
\text { tai bangsa Indonesia karena kita adalah keturu- } \\
\text { nan Indonesia }\end{array}$} & SS & 519 & $25,80 \%$ \\
\hline & & $\mathrm{S}$ & 959 & $47,66 \%$ \\
\hline & & $\mathrm{R}$ & 300 & $14,91 \%$ \\
\hline & & TS & 182 & $9,05 \%$ \\
\hline & & STS & 53 & $2,63 \%$ \\
\hline \multirow{5}{*}{14.} & \multirow{5}{*}{$\begin{array}{l}\text { Organisasi keagamaan dan sosial seperti NU, } \\
\text { Muhammadiyah, Persis, Al-Washliyah, Nahdla- } \\
\text { tul Wathan seharusnya mengembangkan Islam } \\
\text { yang ramah, sejuk, damai dan indah dalam } \\
\text { menjaga kerukunan berbangsa }\end{array}$} & SS & 805 & $40,01 \%$ \\
\hline & & $\mathrm{S}$ & 1007 & $50,05 \%$ \\
\hline & & $\mathrm{R}$ & 183 & $9,10 \%$ \\
\hline & & TS & 14 & $0,70 \%$ \\
\hline & & STS & 4 & $0,20 \%$ \\
\hline \multirow{5}{*}{15.} & \multirow{5}{*}{$\begin{array}{l}\text { Organisasi kemahasiswaan seperti PMII, HMI, } \\
\text { IMM, KAMMI dan lain-lain hendaknya berjuang } \\
\text { untuk kepentingan bangsa dan negara, bukan } \\
\text { untuk kepentingan kelompok dan golongan }\end{array}$} & SS & 848 & $42,15 \%$ \\
\hline & & $\mathrm{S}$ & 963 & $47,86 \%$ \\
\hline & & $\mathrm{R}$ & 177 & $8,80 \%$ \\
\hline & & TS & 14 & $0,70 \%$ \\
\hline & & STS & 11 & $0,55 \%$ \\
\hline \multirow{4}{*}{16.} & \multirow{4}{*}{$\begin{array}{l}\text { Mengembangkan dan menjalankan ajaran Islam } \\
\text { di Indonesia sudah berjalan dengan baik dalam } \\
\text { koridor bangsa Indonesia yang berdasarkan }\end{array}$} & SS & 683 & $33,95 \%$ \\
\hline & & $S$ & 1068 & $53,08 \%$ \\
\hline & & $\mathrm{R}$ & 240 & $11,93 \%$ \\
\hline & & TS & 18 & $0,89 \%$ \\
\hline
\end{tabular}




\begin{tabular}{|c|l|c|c|c|}
\hline & $\begin{array}{l}\text { Pancasila, UUD 1945, NKRI dan Bhinneka } \\
\text { Tunggal Ika }\end{array}$ & STS & 4 & $0,20 \%$ \\
\hline
\end{tabular}

Secara umum dari 16 pertanyaan tersebut tergambar bahwa mayoritas mahasiswa masih berada pada koridor yang sesuai dengan masyarakat Islam Indonesia pada umumnya, mahasiswa yang berpikir moderat berkisar antara 75-85\%, sedangkan yang masih berada di garis abu-abu atau berada pada jawaban keraguan berkisar antara 7-12 \%, dan yang konsisten jawabannya pada garis yang radikal berkisar antara 0-3 \%. Temuan ini terjadi pada hampir semua pertanyaan yang diajukan, terutama yang berhubungan dengan Islam rahmatan lil 'alamin, perbedaan mazhab, pemahaman jihad, pemahaman tentang bid'ah, hubungan Islam dan negara (Indonesia), Pancasila sebagai perekat, pancasila sebagai satusatunya ideologi negara, toleransi beragama, hubungan Muslim dan non-Muslim, tentang radikalisme, nasionalisme, perbedaan organisasi keagamaan, perbedaan organisasi ekstra kemahasiswaan dan eksistensi pengamalan Islam dalam koridor berbangsa dan bernegara.

Tetapi pada satu pertanyaan atau pernyataan yang berhubungan dengan pelarangan HTI ada peningkatan prosentase dari pemahaman yang berlawanan dengan pemahaman yang moderat. $\mathrm{Hal}$ ini menunjukkan adanya intensitas, pemahaman dan propaganda yang banyak berkembang dan difahami oleh mahasiswa sehingga pemahamannya cenderung lebih besar kepada tidak setuju terhadap pelarangan HTI $(10,19 \%)$.

\section{KESIMPULAN}

Berdasarkan pada hasil penelitian ini, dapat disimpulkan bahwa mayoritas mahasiswa Universitas Jambi berada pada corak yang moderat, baik sikap, pemahaman, pengetahuan maupun keyakinannya. Hanya berkisar 0-3\% saja mahasiswa yang konsisten menjawab berbeda dengan pemikiran mainstream. Jumlah ini merupakan akmulasi dari seluruh pertanyaan-pertanyaan yang diajukan kepada responden.
Mahasiswa hendaknya dapat berhatihati dalam memilih kelompok kajian, karena keliru memilih kelompok pengajian akan sangat berpengaruh terhadap perkembangan pemikiran, baik pemikiran keagamaan, kebangsaan maupun tentang hubungan keduanya. Jika terikutkan pada pengajianpengajian atau liqo'-liqo' yang bersifat eksklusif, tertutup dan bersifat radikal maka hendaklah segera melepaskan diri dari ikatan pengajian tersebut, bertanyalah kepada banyak guru, minta pertimbangan dengan orang tua, dosen dan saudara-saudara Muslim yang lain, ikuti pengajian-pengajian mainstream, biasakan untuk menghargai beragam perbedaan pemikiran, agar tidak terjerumus kepada pemikiran radikal, baik dalam beragama maupun dalam bernegara.

\section{DAFTAR PUSTAKA}

Arismunandar, S. (Ed.). (2019). NKRI Bersyariah Atau Ruang Publik yang Manusiawi? Tanggapan 21 Pakar terhadap Gagasan Denny JA. Jakarta: Cahaya Budi Indonesia.

Aryani, D. (2019). Wawancara.

Engineer, A. A. (2004). Islam Masa Kini. Yogyakarta: Pustaka Pelajar.

Fuaduddin, \& Basri, C. H. (2002). Dinamika Pemikiran Islam di Perguruan Tinggi. Ciputat: Logos.

Krippendorff, K. (1993). Content Analysis: Introduction to its Theory and Methodology Terj. Analisis Isi: Pengantar Teori dan Metodologi. Jakarta: Raja Grafindo Persada.

Lusiyana. (2019). Wawancara.

Mubarok, M. M. (2011). Membongkar Rahasia NII, Gerakan NII Makin Subur Sementara NKRI Makin Kabur. Surabaya: Reforma Media.

Muhajir, N. (1992). Metodologi Penelitian Kualitatif. Yogyakarta: Rake Sarasin.

Muhibbuddin, M. (2012). Terapi Hati. Yogyakarta: Buku Pintar.

Peneliti LIPI sebut Organisasi 
Kemahasiswaan Kammi Ajarkan Ideologi Radikalisme. (2016). Diambil 28 Februari 2016, dari http://orbitberita.blogspot.com/2016/ 08/peneliti-lipi-sebut-organisasi.html

Rahmat, M. (2012). Corak Berpikir Keagamaan Mahasiswa. Jurnal Pendidikan Agama Islam - Ta'lim, 10(1), 13-37.

Ramli, A. M. (2004). Cyber Law dan Hak dalam Sistem Hukum Di Indonesia. Bandung: PT Refika Aditama.

Sugiyono. (2001). Statistika Untuk Penelitian. Bandung: Alfabeta.

Syafruddin, D., \& Ismatu, R. (2018). Gen Z: Kegalaun Identitas Keagamaan. Jakarta: PPIM UIN Jakarta.

Turmudi, \& Sihbudi, R. (2005). Islam dan Radikalisme di Indonesia. Jakarta: LIPI Press.

Umar, N. (2019). Islam Nusantara, Jalan Panjang Moderasi Beragama di Indonesia. Jakarta: PT Elex Media Komputindo.

Usman, A. (2006). Kebebasan; Dalam Perbincangan Filsafat, Pendidikan, dan Agama. Yogyakarta: Pilar Media. 